\title{
量子電圧雑音源を利用したボルツマン定数の評価
}

\author{
浦野 千春 ${ }^{*} 1, \dagger$
}

\section{Measurement of the Boltzmann Constant Using a Quantum Voltage Noise Source}

\author{
Chiharu URANO*1,
}

Synopsis: In the new SI, the unit of thermodynamic temperature, Kelvin (K), was defined based on the Boltzmann constant $k$ determined through various thermodynamic temperature measurements. This paper describes a Johnson noise thermometer that uses a quantum voltage noise source, which is a type of precise thermodynamic temperature measurement method.

Keywords: Johnson noise thermometry, Josephson junction, quantum voltage noise, Nyquist equation

\section{1.はじめに}

2018 年 11 月に開催された第 26 回国際度量衡総会におい て、国際単位系 SI の 4 つの基本単位であるキログラム $(\mathrm{kg}) 、 ア ン ヘ ゚ ア （ \mathrm{~A}) 、 ケ ル ヒ ゙ ン （ \mathrm{~K} ）$ およびモル（mol）は 基礎物理定数またはある特定の原子定数によって再定義さ れ、新しい定義による基本単位の運用は 2019 年 5 月から 開始された。この定義改定により、今後測定技術の進歩が あったとしても SI の定義は影響を受ける可能性が無く なった。熱力学的温度の単位であるケルビン $\mathrm{K}$ に関しては、 改定前の SI では「熱力学温度の単位 Kelvin は水の三重点の 熱力学温度の $1 / 273.16 」 と い う$ 形で定義されていた。新し いSI では熱力学温度測定によって今回新たに物理定数と して定義されるボルツマン定数 $k$ に基づいて定義された。

精密な熱力学温度計の技術としては低温から室温付近ま ではボイルーシャルルの法則を基本とした気体温度計 Gas thermometry や、気体音速を音響共鳴で評価する Acoustic Gas Thermometry（AGT）など、広い意味の気体 温度計が世界的に主流である 1)。測定の正確さは AGT が 最良であるが、原理上、特に高温では計測自体が困難とい われている。

これに対して抵抗体の雑音電圧と温度の関係から熱力学 温度を求める Johnson noise thermometry（JNT）は、抵抗体 および信号伝送線路の特性が安定である限り、原理的には 幅広い温度域で適用可能といわれている。JNT は AGT に

Received November 16, 2020

${ }^{* 1}$ 産業技術総合研究所

干305-8563 茨城県つくば市梅園 1-1-1

National Institute of Advanced Industrial Science and Technology,

1-1-1 Tsukuba, Ibaraki 305-8563, Japan

† E-mail: c-urano@aist.go.jp

DOI: $10.2221 /$ jcsj. 56.12
比べて精度は劣るものの、数百 ${ }^{\circ} \mathrm{C}$ といった高温での適用 例もある 2)。JNT では熱力学温度 $T$ に置 かれた抵抗值 $R$ の抵抗器の両端に発生する電圧 $V$ の分散が以下の関係を満 たすといういわゆる Nyquist の式に基づく3)。

$$
\left\langle V^{2}\right\rangle=4 k T R \Delta f
$$

ここで、 $k$ はボルツマン定数、 $\Delta f$ は帯域幅である。

Johnson は式(1)からボルツマン定数を評価し、 $k=$ $1.27 \times 10^{-23} \mathrm{~J} / \mathrm{K}$ という結果を得た（文献中では「1.27×10-16 erg per degree」という現在とは異なる単位が用いられてい る)。この值は当時のボルツマン定数 $\left(1.372 \times 10^{-23} \mathrm{~J} / \mathrm{K}\right)$ よ り $7.5 \%$ 小さい值（現在の值 $1.38064852 \times 10^{-23} \mathrm{~J} / \mathrm{K}$ からは約 $8 \%$ に相当）であったと報告している ${ }^{4)}$

Johnson の実験を現代の観点から眺めると、電圧・抵 抗・温度の測定技術、温度測定技術、温度制御技術、デー 夕収集・解析技術、など、さまざまな要因が測定精度を大 きく制限していたと考えられる。これらの全ての面におい て、1928 年当時と比較して現在はあらゆる面で著しく進 展した。例えば、本手法において本質的に重要な電圧と抵 抗の測定において、量子電圧標準、量子化ホール抵抗標準、 原子時計を利用して絶対值をより精密に測定できるように なっている。さらに、計算機の性能の向上により、パワー スペクトル密度をリアルタイムに計測することが可能と なっている。

米国標準技術研究所（NIST）は量子電圧雑音源 (Quantum Voltage Noise Source, QVNS）を基準として抵抗 器の熱雑音のパワースペクトル密度を精密に測定する方法 を提案した ${ }^{5,6)}$ 。量子電圧雑音源はジョセフソン接合ア レーを利用した疑似乱数発生装置であり、そのパワースペ

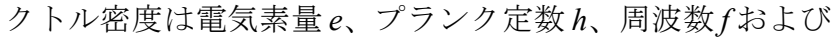
数值係数で記述可能である。加えて、抵抗器の抵抗值も量 


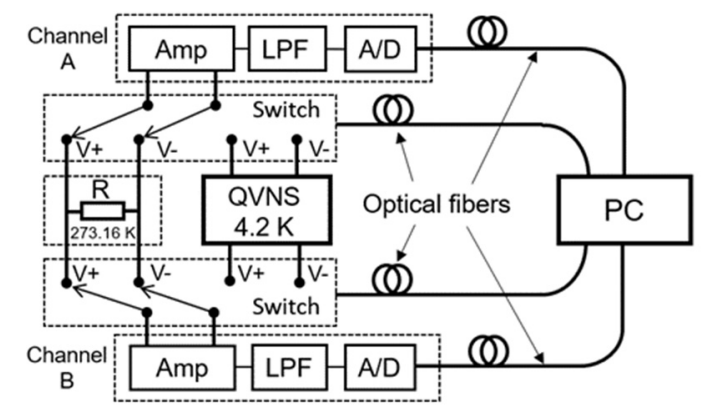

Fig. 1 A schematic diagram of the measurement system for the Johnson noise thermometer using a Quantum Voltage Noise Source (QVNS).

子化ホール抵抗を基準とした測定によって精密に測定可能 である。この手法が開発されたことで、ジョンソン雑音温 度計の性能が大幅に向上寸る可能性が広がった。

\section{2. 量子電圧雑音源を用いた Johnson 雑音温度計}

装置全体の構成を Fig. 1 に示す。測定システムは大きく 分けて抵抗温度計、基準信号源となる QVNS、サンプル切 り替えスイッチ、増幅器 (Amp)、ローパスフィルター $(\mathrm{LPF}) 、 \mathrm{~A} / \mathrm{D}$ 変換器、およびデータ収録用の計算機からな る。サンプル切り替えスイッチによって抵抗温度計あるい は QVNS からの信号の一方を交互に一定時間おきに選択 する。それらの信号は、特性が揃った 2 チャンネルの増幅 器、LPF、A/D 変換器を通して同時に測定される。

グランドループ除去のため、サンプル切り替えスイッチ、 アンプ、A/D 変換器はバッテリー駆動であり、サンプル切 り替えスイッチおよび $\mathrm{A} / \mathrm{D}$ 変換器の計算機からの制御信 号は全て光ファイバーを利用している。

抵抗温度計部では、温度センサーとなる抵抗器が、水の 三重点温度となるように設置されている。水の三重点は、

Fig. 2(a)に示されるような水が封入されたガラス容器を用 いて実現される。水をガラス容器に封入する際には、真空 ポンプで引きながら封じ切られており、液体の水で満たさ れていない部分は水蒸気で満たされている。水の三重点温 度はこの容器内の水の一部を凍らせて、液体の水、水、水 蒸気が共存する状態を実現することにより得られる。3つ の相が共存する境界部分の温度は、Fig. 2 (b)に示される水 の相図上で気体・液体・固体の 3 相が共存する温度となる。 この温度を水の三重点温度 $T_{\mathrm{TPW}}$ と呼ぶ。三重点では比熱 が発散しているため、少量の熱の出入りに対しても温度変 化は無視できるほど小さい。

水の三重点セルの中心部分には試験管のようなガラス チューブが挿入された構造となっており、そのチューブに 抵抗温度センサーが装着された抵抗温度プローブを挿入し、 チューブと抵抗温度プローブの間を熱媒体で満たすことに より、抵抗器の温度を水の三重点となるようにする。抵抗 (a)

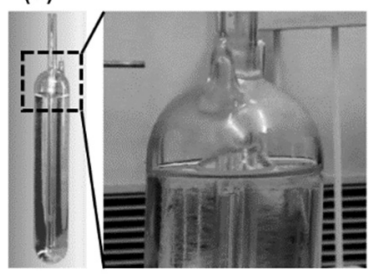

(b)

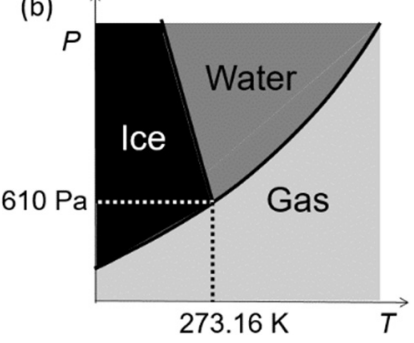

Fig. 2 (a) Triple point of water cell. (b) Water phase diagram.

器は水の三重点が実現する水面部分より深いところにある ため、水圧補正を施す必要がある。その他、抵抗温度セン サーに取り付けられた導線による熱流入にも注意する必要 がある。温度センサーの抵抗值は量子化ホール抵抗標準に より校正された標準抵抗器を基準に精密に測定する。

式(1)によると、抵抗温度センサーの抵抗值が大きけれ ば大きいほど雑音電圧が増大するが、高い精度で測定する ことは必ずしも簡単ではない。抵抗值が直接接続する増幅 器が観測する電圧は抵抗温度センサーと増幅器の入力イン ピーダンスで分圧されるため、抵抗温度センサーの抵抗值 は入力インピーダンスと比較して、圧倒的に小さい必要が ある。また、抵抗温度センサーの出力信号の周波数特性は、 抵抗温度センサーの抵抗と信号の読み出しに使うケーブル のキャパシタンスからなる RCフィルターを通して観測さ れることになる。そのため、抵抗值の増大とともに信号強 度は増大する一方、帯域は減少してしまう。さらに信号増 大は非線形歪を引き起こす危険性もある。一方、抵抗值が 低すぎて信号対雑音比が低くなればなるほど、統計的な不 確かさが増大し、後に説明する幾つかのテクニックを利用 しても、測定にかかる時間が非常に長くなってしまう。こ のような条件から、6 桁以上の精度で測定するには、抵抗 温度センサーの抵抗值としては高々 $100 \Omega$ 程度が適切と考 えられる。

水の三重点温度における $100 \Omega$ の抵抗温度センサーの熱 雑音は $1.228 \mathrm{nV} / \sqrt{\mathrm{Hz}}$ となる。この值は、市販の低雑音増幅 器の入力換算電圧雑音密度と同程度である。したがって、 初段の増幅器として入力換算電圧雑音密度が極力小さいも のを採用することが重要である。単一の測定チャンネルで、 この大きさの信号を市販の低雑音増幅器で測定すると、抵 抗温度センサーの雑音電圧に増幅器の雑音が足しあわされ たものが観測される。このため、単一の測定チャンネルで 抵抗の雑音電圧のみを精密に求めることは不可能である。 この問題を克服するために、特性が揃った 2 つの測定チャ ンネルで同一の信号を測定し、相関を計算することによっ て抵抗温度センサーの寄与のみを抽出するというテクニッ クが利用される。相関により微小な雑音信号を計測する技 術は雑音測定で広く利用されている。2つの測定チャンネ 


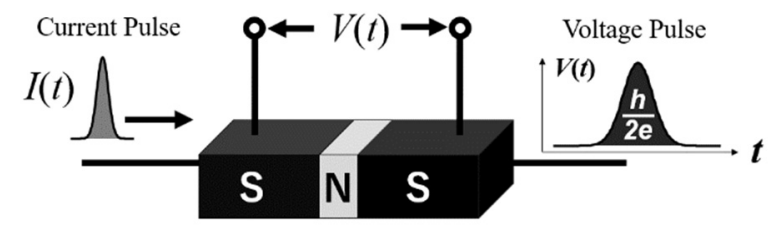

Current pulse trains modulated

Output voltage $V(t)$

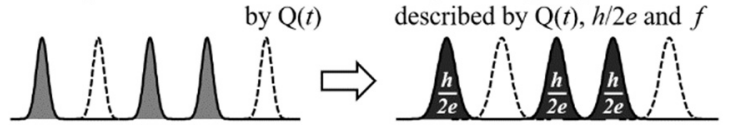

Fig. 3 An explanation of the function of a Josephson junction and the principle of quantized arbitrary voltage waveform generation.

ルから得られたデータは計算機上でフーリエ変換され、ク ロススペクトルが計算される。クロススペクトルを長時間 積算すると相関の無い信号からの寄与は相殺され、2つの チャンネルに共通する信号成分のみ抽出することができる。 式(1)を $k$ にいて解くためには、左辺の絶対值を決める 必要がある。そのためには、広い周波数領域における電圧 の基準が必要不可欠である。その基準信号として用いられ るものが QVNS である。QVNS で発生した疑似白色信号の スペクトルと抵抗温度計のスペクトルを交互に測定し、パ ワースペクトル密度の比を求めることにより増幅器のゲイ ンを校正しながら抵抗温度計のスペクトルの絶対值を精密 に測定することができる。次節ではQVNSについて詳しく 述べる。

\section{3. 量子電圧雑音源}

\section{1 ジョセフソン接合}

量子電圧雑音源はジョセフソン接合とよばれる超伝導デ バイスを使って実現される。ジョセフソン接合とは、Fig. 3 に示すように 2 つ超伝導体によって金属や絶縁体などの 薄い非超伝導体を挟んだ構造のデバイスである。超伝導電 極閒が絶縁体のジョセフソン接合を SIS 接合、金属のもの を SNS 接合という（S、I、N は Superconductor、Insulator、 Normal metal を表す)。

2 つの超伝導電極間の障壁をクーパー対がトンネルする ことによって、巨視的波動関数の位相は相関を持つ。2つ の超伝導電極間の巨視的波動関数の位相差を $\phi$ とすると、 トンネル障壁を通して $i=i_{0} \sin \phi$ とあらわされる非散逸のト ンネル電流が流れる7)。i $i_{0}$ は臨界電流であり、超伝導体の温 度、エネルギーギャップ、超伝導電極間のトンネル抵抗の 関数となっている。ジョセフソン接合の等価回路は、この トンネル電流を流す電流源と、抵抗器、キャパシターが並 列に接続したモデルでよく記述できる ${ }^{8)}$ 。QVNS において はて電流一電圧特性にヒステリシスが無いことが必要であ るため、SNS 接合や超伝導電極間を抵抗で短絡されたもの が利用される。

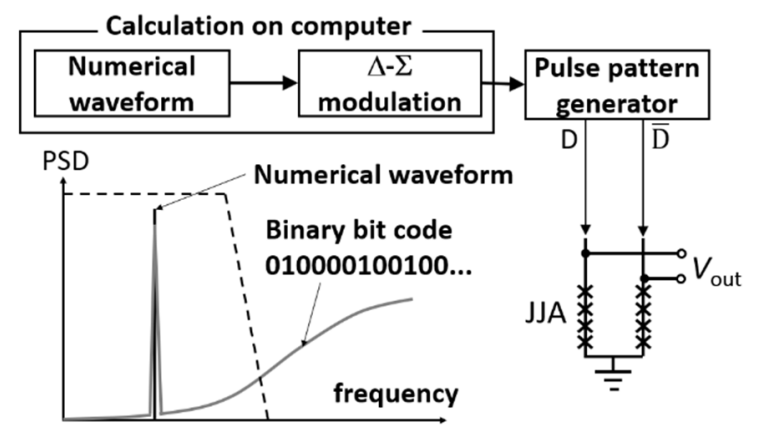

Fig. 4 Operating principle of the Josephson arbitrary waveform generator using $\Delta-\Sigma$ modulation.

\section{2 ジョセフソン任意波形発生器による量子電圧雑音源}

Fig. 3 に示すように、ジョセフソン接合に適切な条件のパ ルス電流を入力すると、両端の超伝導電極間には面積が $h / 2 e$ の整数倍の電圧パルスが発生する。電流パルスとして 直流オフセット電流が重畳した周波数 $f$ のマイクロ波を用 いた場合、超伝導電極間には $h f / 2 e$ の平均電圧が発生する。 これは電圧標準として利用されている。マイクロ波パルス をデジタル回路によって時間的に変調（ON/OFF）するこ とによって変調してやれば、発生する電圧パルス列は変調 信号に用いたデジタル信号列と同じで、かつ、それぞれの パルスの面積が厳密に $h / 2 e$ 倍になったものが出力される。 この原理を利用して、ジョセフソン接合を用いた、最高に 精度の高い任意波形発生器を構成することができる。

具体的には、まず、実際に出力したい波形を数值的に表 現したアナログ波形を計算機上で生成する。例えば、正弦 波を生成したいとすると、周波数領域ではパワースペクト ル密度はFig. 4 中の黒線で示されるような単一トーンと なっている。次にこのアナログ波形をデジタル波形に変換 する。この変換を行う際に、高精度のオーディオプレー ヤーなどで用いられている $\Delta-\Sigma$ 変調と呼ばれる、一種の 粗密変調を用いると、変換に伴い量子化誤差が付随するた め、周波数ドメインでは Fig. 4 に示すように、信号の単一 トーンに加えて周波数に依存した量子化誤差が乗ったスペ クトルに変化する。不要な周波数帯を急峻なローパスフィ ルターで除去することにより、所望の帯域の信号対雑音比 を選択的に高くすることが可能となる。

このように生成したデジタル信号列をパルスパターン発 生器あるいは任意波形発生器のメモリーに記録し、マイク ロ波パルス（電流パルス）としてジョセフソン接合に入力 する。ジョセフソン接合アレーは電流パルス列を量子化さ れた電圧パルス列に波形成型する。パルスパターン発生器 や高周波任意波形発生器は非常に高価な装置である。

この変調法を用いて、NIST はジョセフソン接合を利用し た任意波形生成器で疑似白色雑音を生成し、ジョンソン雑 音温度計の基準信号源として利用する方法を提案した ${ }^{5,6)}$ 。 


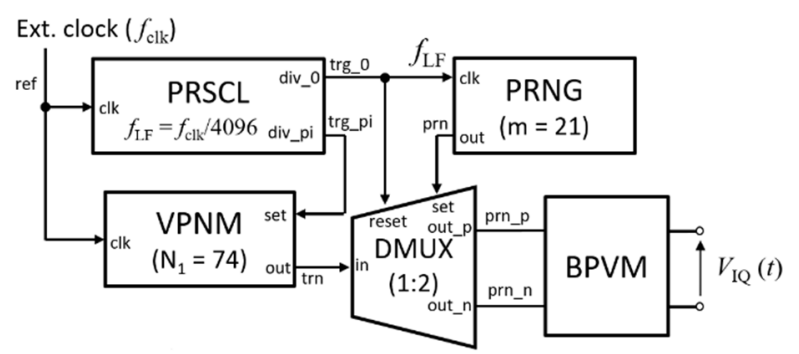

Fig. 5 A block diagram of integrated QVNS. PRSCL, PRNG, VPNM, DMUX, and BPVM stands for the prescaler, pseudo-random noise generator, voltage pulse number multiplier, demultiplexer and bipolar voltage multiplier, respectively.

\section{3 疑似乱数発生器を内蔵した集積型量子電圧雑音源}

NIST Q QVNS は疑似白色雑音の生成のための計算コスト が高い。また、ジョセフソン接合アレーを駆動するために 高価なパルスパターン発生器が必要となる。産総研では、 量子化された疑似白色雑音を発生するための全ての機能を 一つの素子上に全て実装した、集積型量子電圧雑音源 （Integrated QVNS、IQVNS）を開発した。IQVNS は単一磁 束量子理論に基づいたデバイスであり、擬似乱数発生回路 を含めた全ての回路要素が超伝導集積回路技術を用いて一 つのチップ上に実装されている ${ }^{9-13)}$

Fig. 5 は IQVNS のブロックダイアグラムである。IQVNS に入力すべき信号は回路のクロック信号のみである。従来 型の QVNS ではパルスパターン発生器からジョセフソン接 合アレーに入力するマイクロ波パルスで直接駆動するた め、その振幅は大きい必要があった。それに対し、IQVNS に入力するクロック信号は変調されたマイクロ波パルスで なく、単一トーンのマイクロ波でかつ振幅も小さくて良い ため、室温側のエレクトロニクスが安価で済む。

IQVNS の内部では、外部から入力されたクロック信号 (周波数 $f_{\mathrm{clk}}$ ）をプリスケーラ（PRSCL）で $1 / 4096$ に分周し た内部クロック信号（周波数 $f_{\mathrm{LF}}$ ）を生成し、疑似乱数発生 回路（PRNG）や電圧パルス数増倍器（VPNM）、デマルチ プレクサ（DMUX）の駆動に利用する。VPNM はクロック パルスが入力されるたびに $N_{1}(=74)$ 個のパルス列を発生 する回路である。DMUX は PRNG で生成された 2 進の疑似 乱数とその補数を用いて VPNM の出力パルス列を ON/OFF する回路である。バイポーラ電圧増倍器（BPVM）は超伝 導量子干渉素子（SQUID）が直列に $N_{2}(=4)$ 個結合された SQUID アレー 2 本からなる。DMUXからの 2 つの相補的な 出力信号を BPVM に入力することにより、振幅が $N_{2}$ 倍の バイポーラ信号が出力される。

PRNG では、いわゆる M 系列とよばれる代数的な原理に 基づいて疑似乱数を生成する ${ }^{14)}$ 。 M 系列生成回路はフィー ドバックのあるシフトレジスタを用いて構成される。擬似 乱数信号のコード長 $M$ はシフトレジスタの段数 $m$ を用いて

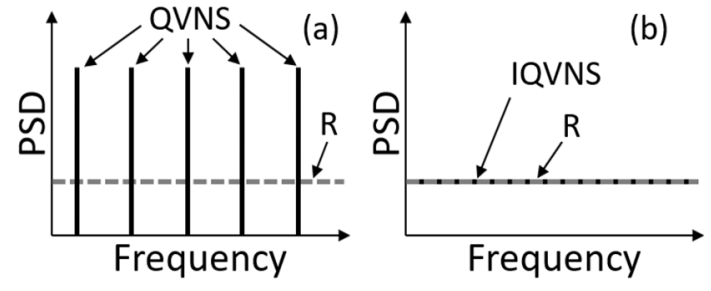

Fig. 6 Schematic diagram of the power spectral density (PSD) for (a) QVNS and (b) integrated QVNS. The Johnson noise of a resistor, $\mathrm{R}$, is also shown.

$M=2^{m}-1$ と表される。文献 9〜13)では $m=21$ を採用した。 単純な回路を用いて繰り返し周期の長い疑似乱数波形を発 生できることが、本方式の大きな特徵である。周波数ゼロ における IQVNS のパワースペクトル強度 $P S D_{\mathrm{IQ}}(0)$ は、上記 の $M 、 N_{1} 、 N_{2} 、$ および $f_{\mathrm{LF}}$ を用いて

$$
P S D_{\mathrm{IQ}}(0)=2(M+1) N_{1} N_{2}\left(\frac{h}{2 e}\right)^{2} f_{\mathrm{LF}}
$$

と表される。式(2)における $h$ と $e$ はプランク定数および電 気素量である ${ }^{9-13)}$ 。

従来型の QVNS では出力信号の繰り返し周期はパルスパ ターン発生器のメモリー容量で制限される。このため、サ ンプリング周波数が十分高いと、周波数領域におけるトー ンの間隔は Fig. 6 (a)に示すような櫛状のものになり、抵抗 器の白色ノイズと大きく異なるように見えることになる。 一方、IQVNS に関しては、小規模の回路で長周期の擬似乱 数信号を発生することが可能であり、Fig. 6 (b)に示すよう 従来型の QVNS と比べて 100 倍高いサンプリング周波数で も抵抗器と同様な白色ノイズに見える信号を発生すること ができている ${ }^{15,16) 。}$

\section{4. ボルツマン定数の評価結果}

産総研では IQVNS の発生する量子電圧雑音を基準とし てジョンソン雑音を測定するシステムを開発した。この装 置を用いて水の三重点 $(273.16 \mathrm{~K})$ に置いた $100 \Omega$ の抵抗 器の熱雑音のパワースペクトルを 6 日間測定した。Fig. 7 にIQVNS と $100 \Omega$ の抵抗器のクロスパワースペクトルと オートパワースペクトルが示されている。積算時間はとも に 100 秒間である。オートパワースペクトルとクロスパ ワースペクトルの差は増幅器や途中の配線など、相関の無 い雑音に起因し、クロスパワースペクトルでは長時間積算 によりそれらが除去されているのが分かる。Fig. 7 (b)にお いて $1 \mathrm{kHz}$ 付近から数百 $\mathrm{MHz}$ 付近の範囲で見えている平 坦な部分が式(1)で表されるものに対応する。クロスパ ワースペクトルにおいて $100 \mathrm{~Hz}$ 程度以下で見られる落ち 込みは $1 / f$ ノイズを除去するためのローパスフィルターに よる影響である。一方、 $1 \mathrm{MHz}$ 付近より高い周波数で見ら れる急激な減少はアンチエリアシングフィルターによるも 


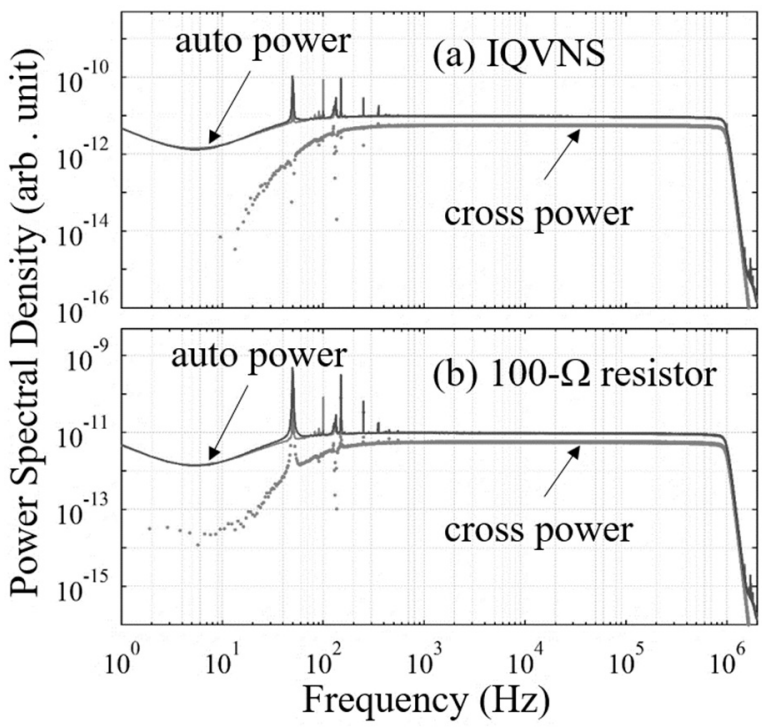

Fig. 7 Cross-power spectral density and auto-power spectral density of an (a) IQVNS and (b) a $100-\Omega$ resistor.

のである。IQVNS の出力電圧波形は周期が約 $1.049 \mathrm{~Hz}$ の 周期信号のため、本質的には離散的なスペクトルを持つが、 約 $0.954 \mathrm{~Hz}$ の周波数分解能で観測する場合、Fig. 7 (a)に示 すように抵抗器の熱雑音と同様に連続スペクトルのように 見える。両者のクロススペクトルどうしの比を求めれば、 式(1)と式(2)によりボルツマン定数を計算することができ る。測定により得られたボルツマン定数 $k$ の值は $k=$ $1.3806436 \times 10^{-23} \mathrm{JK}^{-1}$ 、相対合成不確かさは約 $10 \mathrm{ppm}$ となっ た ${ }^{17)}$ 。この值は Fig. 8 に示すように、2017 年 CODATA 值 よりも相対的に $4 \mathrm{ppm}$ 程度小さい值であるが、相対合成不 確かさの範囲で整合している ${ }^{18)}$

\section{5. まとめと今後の展望}

産総研では集積型量子電圧雑音源 IQVNS および IQVNS が発生する信号を基準としたジョンソン雑音温度計を開発 した。このジョンソン雑音温度計を用いて水の三重点に設 置した抵抗器の熱雑音を測定することにより、ボルツマン 定数 $k$ を求めた。ジョンソン雑音の測定によるボルツマン 定数の決定に成功しているのは世界でも 3 つの研究機関の みである。我々の実験で得られたボルツマン定数は、他の 独立な測定方法による結果と $10 \mathrm{ppm}\left(10^{-5}\right)$ の精度で整合 し、その定義值の決定の正当性を確固とした。2018 年に 国際度量衡総会で決議され、2019 年には利用が開始され ることが予定されている改定国際単位系の制定に貢献をす ることができた。

熱力学温度の測定は、時間と労力がかかり、容易でない ことから、通常の温度测定では、熱力学温度の最良近似と して国際的に採択されている 1990 年国際温度目盛（ITS90）が利用されている ${ }^{19)}$ 。ITS-90 は物質の三重点や金属の 凝固点などを利用した温度定点（定義定点）の温度值を国

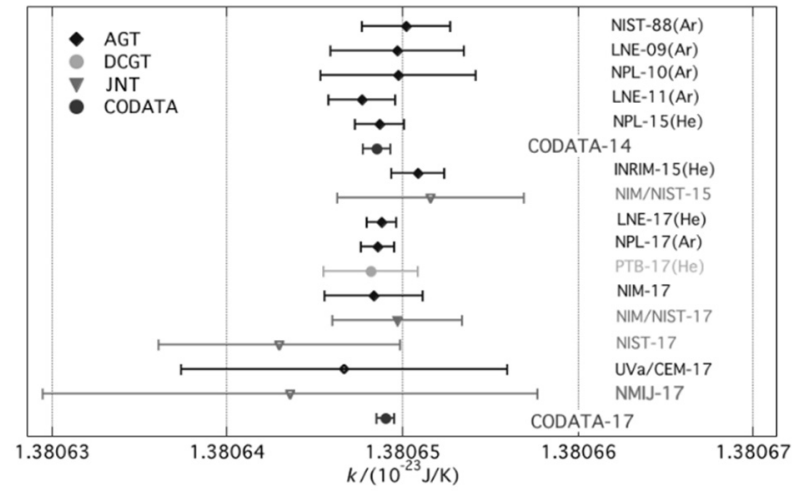

Fig. 8 Boltzmann's constant determined using various thermodynamic temperature measurement methods: AGT, DCGT, and JNT stand for acoustic gas thermometer, dielectric constant gas thermometer, and Johnson noise thermometer, respectively.

際協約として定義し、所定の方法で温度定点の間を補間す ることで実現されている。しかし、近年の科学技術の進展 に伴い、実用的な ITS-90（ $\left.T_{90}\right)$ と普遍的な熱力学温度值 $(T)$ との差異があることが分かってきている。また、ボル ツマン定数 $k$ に基づくSI 単位の定義変更に伴い、ITS-90 と熱力学温度の差（ $T-T_{90} ）$ を高精度、かつ、広い温度範 囲により再評価する機運が高まっている。SI 単位の定義 変更後も、国際的には当面の間は ITS-90 を変更しない方 針とされているが、単位の定義と実用される目盛との乘離 は科学として不自然であるため、基礎データを蓄積した上 でこれらが一致する方向への改定を提案すべきと考えてい る。

\section{参 考 文 献}

1) J. Fischer, et al.: "Preparative steps towards the new definition of the Kelvin in terms of the Boltzmann constant", Int. J. Thermophys. 28 (2007) 1753-1765

2) W. L. Tew, et al.: "Johnson noise thermometry near the zinc freezing point using resistance-based scaling," Int. J. Thermophys. 28 (2007) 629-645

3) H. Nyquist: "Thermal agitation of electric charge in conductors," Phys. Rev. 32 (1928) 110-113

4) J. B. Johnson: "Thermal agitation of electricity in conductors," Phys. Rev. 32 (1928) 97-109

5) S. P. Benz, et al.: "A new approach to Johnson noise thermometry using a Josephson quantized voltage source for calibration," Proceedings of TEMPMEKO 2001 (2002) 37-44

6) S. P. Benz, et al.: "An AC Josephson source for Johnson noise thermometry," IEEE Trans. Instrum. Meas. 52 (2003) 545-594

7) B. D. Josephson: "Possible new effects in superconductive tunnelling,” Phys. Lett. 1 (1962) 251-253

8) A. バローネ, G. パテルノ：「ジョセフソン効果の物理と応 用」, 近代科学社, 東京 (1988)

9) M. Maezawa, T. Yamada and C. Urano: "New quantum voltage noise source for Johnson noise thermometry," in Program and Proc. 
5th Superconducting SFQ VLSI Workshop, Nagoya, Japan (2012) $67-70$

10) M. Maezawa, T. Yamada and C. Urano: "Integrated quantum voltage noise source for Johnson noise thermometry," J. Phys.: Conf. Ser. 507 (2014) 042023

11) T. Yamada, M. Maezawa and C. Urano: "Design and test of component circuits of an integrated quantum voltage noise source for Johnson noise thermometry," Physica C 518 (2015) 85-88

12) M. Maezawa, T. Yamada and C. Urano: "Improved design of integrated quantum voltage noise source," IEEE Trans. Appl. Supercond. 26, no.3 (2016) 1800504

13) T. Yamada, C. Urano and M. Maezawa: "Demonstration of Johnson noise thermometry with all-superconducting quantum voltage noise source," Appl. Phys. Lett. 108 (2016) 042605

14) A. C. Arvillias and D. G. Maritasas: "Partitioning the period of a class of m-sequences and application to pseudorandom number generation,” J. Assoc. Computing Machinery 25 (1978) 675-686

15) C. Urano, T. Yamada and M. Maezawa: "Johnson noise thermometry based on integrated quantum voltage noise source," IEEE Trans. Appl. Supercond. 26, no. 3 (2016) 1800305

16) C. Urano, et al:: "Measuring the Boltzmann's constant using superconducting integrated circuit," IEEE Trans. Instrm. Meas. 66 (2017) 132-138
17) C. Urano, K. Yamazawa and N. Kaneko: "Measurement of the Boltzmann constant by Johnson noise thermometry using a superconducting integrated circuit," Metrologia 54 (2017) 847-855

18) Peter J Mohr, et al.: "Data and analysis for the CODATA 2017 special fundamental constants adjustment," Metrologia 55 (2018) 125-146

19) H. Preston-Thomas: "The international temperature scale of 1990 (ITS-90),” Metrologia 27 (1990) 3-10

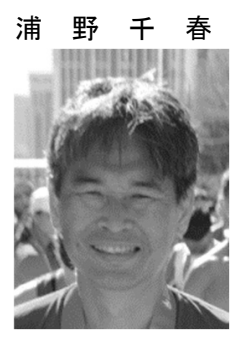

1971 年 4 月 14 日生。1995 年東京大学工学 部物理工学科卒業。2000 年同大学院工学研究 科博士前期課程（超伝導工学専攻）修了。 2002 年 産業技術総合研究所入所。2007 年国 際度量衡局 (BIPM) 訪問研究員。2010 年米 国国立標準技術研究所（NIST）訪問研究員。 日本物理学会, 応用物理学会会員。博士（工 学)。 